\title{
Influence of water having variable salinity and sodicity on groundnut-II : Effect on nutrient content and uptake
}

R.D. Meghwal, J.V. Polara and K.B. Ranpariya

Received : 22.08.2020; Revised : 08.11.2020; Accepted : 20.11.2020

\author{
MEMBERS OF RESEARCH FORUM: \\ Corresponding author : \\ J.V. Polara, Department of \\ Agricultural Chemistry and Soil \\ Science, Junagadh Agricultural \\ University, Junagadh (Gujarat) \\ India \\ Email: jvpolara@jau.in
}

Co-authors :

R.D. Meghwal and K.B.

Ranpariya, Department of Agricultural Chemistry and Soil

Science, Junagadh Agricultural

University, Junagadh (Gujarat)

India

\section{Summary}

A pot experiment was conducted at Net House, Department of Agricultural Chemistry and Soil Science, College of Agriculture, Junagadh Agricultural University, Junagadh to assess the different levels of saline and sodic irrigation water on content and uptake of nutrient by groundnut during the Summer-2018. The treatment consists of four levels each of salinity (2, 4,6 and $\left.8 \mathrm{dS} \mathrm{m}^{-1}\right)$ and sodicity $(5.0,10.0,15.0$ and $20.0 \mathrm{SAR})$ of irrigation water by adopting factorial CRD with three replications. The results indicated that application of different levels of saline and sodic irrigation water produced significant effect on content and uptake of $\mathrm{N}, \mathrm{P}$ and $\mathrm{K}$ by kernel and haulm of groundnut. The highest $\mathrm{N}, \mathrm{P}$ and $\mathrm{K}$ content $(3.76 \%, 0.34 \%$ and $0.67 \%$ ) and uptake (163.6, 13.34 and $\left.25.14 \mathrm{mg} \mathrm{pot}^{-1}\right)$ by kernel and content $(1.08 \%, 0.15 \%$ and $0.40 \%)$ and uptake $\left(177.8,25.01\right.$ and $\left.66.5 \mathrm{mg} \mathrm{pot}^{-1}\right)$ by haulm, respectively were observed with $\mathrm{EC}-2 \mathrm{dS} \mathrm{m}^{-1}$ level of salinity of irrigation water, but the lowest content and uptake by kernel were observed with EC-6 dS m$~^{-1}$ and by haulm at EC- $8 \mathrm{dS} \mathrm{m}^{-1}$ levels of salinity of irrigation water. There was no any pod formation were observed with EC-8 dS m$~^{-1}$, hence, content and uptake of nutrients by kernel considered zero. While the highest $\mathrm{N}, \mathrm{P}$ and $\mathrm{K}$ content $(2.85 \%$, $0.22 \%$ and $0.42 \%)$ and uptake $\left(109,5.93\right.$ and $\left.11.45 \mathrm{mg} \mathrm{pot}^{-1}\right)$ by kernel and content $(1.01 \%$, $0.13 \%$ and $0.37 \%$ ) and uptake $\left(135.5,17.80\right.$ and $\left.48.6 \mathrm{mg} \mathrm{pot}^{-1}\right)$ by haulm, respectively were observed with SAR- 5.0 level of sodicity of irrigation water. The interaction effect between salinity and sodicity levels of irrigation water on concentration and uptake of $\mathrm{N}$ by kernel and haulm were found significantly the highest with $\mathrm{C}_{1} \times \mathrm{S}_{1}\left(\mathrm{EC}-2.0 \mathrm{dS} \mathrm{m}^{-1} \times \mathrm{SAR}-5.0\right)$ level of salinity and sodicity of irrigation water.

Key words : Groundnut, Salinity, Sodicity, Content, Uptake, Macro nutrients

How to cite this article :Meghwal, R. D., Polara, J. V. and Ranpariya, K. B. (2020). Influence of water having variable salinity and sodicity on groundnut-II : Effect on nutrient content and uptake. Asian J. Soil Sci., 15(2): 101-104 : DOI : 10.15740/HAS/AJSS/15.2/101-104. Copyright@2020: Hind AgriHorticultural Society.

\section{Introduction}

Salinity and sodicity is one of the most serious factors limiting crops production and salinity reduces the ability of plants to take up water, leading to growth reduction as well as metabolic changes similar to those caused by the water stress. High salt concentration in root affects 